\title{
ADVANTAGE OF LATERITE OVER CLAY IN THE MANUFACTURE OF COMPRESSED STABILIZED EARTH BRICKS (CSEBs)
}

\author{
Priji E. Moses
}

PhD-Scholar, Department of Civil Engineering, Bharath Institute of Higher Education and Research (BIHER), Chennai, India.

\section{Dr. M.P. Chockalingam*}

Professors, Department of Civil Engineering, Bharath Institute of Higher Education and Research (BIHER), Chennai, India.

\section{Dr. R. Venkatakrishnaiah}

Professors, Department of Civil Engineering, Bharath Institute of Higher Education and Research (BIHER), Chennai, India.

\section{Prof. P. Dayakar}

Professors, Department of Civil Engineering Bharath Institute of Higher Education and Research (BIHER), Chennai, India. *Corresponding Author : chockalingammp@gmail.com

\begin{abstract}
Compressive strength characteristics and Rate of Water Absorption are the two important factors in the choice of soil types for the manufacture of Compressed Stabilised Earth blocks. Cement was used as the stabilizing agent in Laterite soil, in the ratio of cement : soil=1:10. Similar proportion was used in the Clay Soil mix. After thoroughly mixing the soil mass, with sufficient quantity of water for each set of specimens, casting of blocks was carried out using standard moulds. Compaction is done at 14.0MPa, 21.0 MPa and 28.0MPa. The compressed Stabilised Earth Blocks are born. After removing the blocks from the mould, curing is done as per standard procedures. Tests were conducted on the specimens for i) Compressive strength, and ii) Moisture Absorption rate. The compressive strengths were achievable on the $28^{\text {th }}$ day of Curing Age, was $7.45 \mathrm{~N} / \mathrm{sq} . \mathrm{mm}$ at $28.0 \mathrm{MPa}$ of compaction in the case of Laterite Block, and $5.05 \mathrm{~N} / \mathrm{sq} . \mathrm{mm}$, in the case of Clay Block. The rate of Moisture Absorption was $14.95 \%$ on the $28^{\text {th }}$ day, at a compaction of $28.0 M P a$, in the Laterite Block. The corresponding Moisture Absorption rate in Clay Block was 21.05\%.

Laterite Blocks give a compressive strength of $7.45 \mathrm{~N} / \mathrm{sq} . \mathrm{mm}$, and Clay Blocks give a compressive strength of $5.05 \mathrm{~N} / \mathrm{sq} . \mathrm{mm}$, when $10 \%$ cement is added and a compaction of 28.0MPa is applied, in both cases, in the manufacturing process.
\end{abstract}


Keywords: Laterite soil-Clay soil-Compressed Stabilised Earth Block- Comparison of Compressive strengths

Cite this Article: Priji E. Moses, Dr. M.P. Chockalingam, Dr. R. Venkatakrishnaiah, P. Dayakar, Advantage of Laterite over Clay in the Manufacture of Compressed Stabilized Earth Bricks (CSEBs), International Journal of Advanced Research in Engineering and Technology (IJARET), 11 (1), 2020, pp 45-51.

http://iaeme.com/Home/issue/IJARET?Volume=11\&Issue $=1$

\section{INTRODUCTION}

Earthen structures have been in use in the ancient society all over the world, during the past several centuries. In the present context, more housing requirements are needed, at the advent of the ever-increasing population. Mostly, in rural areas, the earthen structures in a modified form has become popular. The development of compressed Stabilised Earth Block is considered as an innovative material. The main considerations are cost-effectiveness, local acceptability, rural employment, durability of the structure, fire-resistance, thermal insulation, etc . Many researchers have made contributions in this regard $(1,2,3,4,5)$.

Raul Ramirez (6) introduced the concept of Compressed Stabilised earth Blocks, in the year 1950, in Bogota City (Columbia). Rigassi,et.al, (7) published a Manual on Production of Compressed Earth Blocks. Auroville Earth Institute (8), under the auspices o UNESCO-Chair on Architecture, took efforts in India to popularize the Earth Block construction methods, using Laterite soil, with innovative instrument technology.

In all the States of South India, namely, Tamil Nadu, Kerala, Andhra Pradesh, Telangana and Karnataka, there are many areas where Laterite soil is available as a resource. This is an encouraging factor for the promotion of Compressed Stabilised Earth Block system of housing to flourish and become popular in rural areas, in the Government-sponsored housing schemes as well as "Build Your Homes Scheme" funded by Government Agencies with financial subsidies to the beneficiaries.

In Malaysia, manual method of manufacturing earth blocks were in use since the year 1950, and at some stage, the hydraulic compression machine was introduced in the process of making CSEBs, perhaps, in large scale operations (9).

Abdullah, et.al (10) concluded that Laterite soil was found satisfactory as a raw material in the production of CSEBs, in a mix ratio of Cement: Soil : Sand =1: $8: 2$, with water absorption ratio of $14.5 \%$ on $28^{\text {th }}$ day of curing.

Soil requirement for making compressed Stabilised Earth Blocks (CSEBs) are, in general terms, i) gravel @15\%, ii) sand@50\%, iii) silt@15\% and iv) clay@20\%, plus Ordinary Portland Cement (OPC). However, the soil requirement differs between dry climate regions and tropical climate regions (10). This factor necessitates the need for experimental trials at each site.

Laterite, as a soil category, contains clay and iron particles. Clay and Laterite have got differences in quality characteristics of porosity, moisture holding capacity, hardening, compressibility, etc (11). Ordinary Portland Cement (OPC) is considered as a good stabilizing ingredient used for making CSEBs (12).

Sand, as a material used in the manufacturing of CSEBs, must be free from organic substances, and must be of finer size (passing through $2 \mathrm{~mm}$ sieve ), and be clean (without impurities).

Ordinary Portland Cement (OPC) has been identified as a good stabilizing agent, as it can be used in any type of climatic conditions (12). 
Water, as an important ingredient in the soil mix, must be of satisfactory qualities, such as neutral $\mathrm{pH}$-value, freedom from organic or chemical impurities, especially freedom from sulphates. Impurities in water would affect the hydration of cement. The role of water is very important during the hardening process, especially during the Curing Age . The quantum of water needed in the manufacturing of CSEBs varies from $10.0 \%$ to $20.0 \%(10,11)$.

\section{AIM OF THE STUDY}

The Study was aimed at evaluating the merits of using Laterite soil in manufacturing Compressed Stabilised Earth Blocks, in comparison to Clay, in respect of Compressive Strength and Moisture Absorption Rate.

\section{METHODOLOGY}

The Laterite soil is mixed with sand and cement as Specimen-1. Clay is mixed with sand and cement as Specimen-2. Water is mixed up to the point of optimum consistency in each case. Ordinary Portland Cement (OPC) is used in both cases. The Cement : Soil : Sand ratio of 1:8:2 was used for Laterite Specimen. The Cement : Soil : Sand ratio of 1:5:5 was used for Clay Specimens. The soil grain sizes in Laterite and Clay were in such a way that the particles passed through $0.425 \mathrm{~mm}$ sieve.

Laterite soil contained $5.7 \%$ of Clay, $78.7 \%$ of sand and $15.7 \%$ of gravel. The Clay specimen consisted of $18.1 \%$ of clay, $73.0 \%$ of sand and $8.9 \%$ of mud.

The Plasticity Index (PI) of Laterite specimen was 21.70, with liquid limit of $44.5 \%$ and Plastic Limit of $22.8 \%$. The Plasticity Index (PI) of Clay specimen was 35.72, with Liquid Limit of $67.75 \%$ and Plastic Limit of $32.03 \%$.

The soil mixes were prepared in each case of Laterite Specimen and Clay Specimen. The soil pastes were filled up in the mould, and compacted adopting three levels of compaction, namely, 14.0MPa, 21.0MPa, and $28.0 \mathrm{MPa}$, on the two sets of Specimens. A standard mould of $230 \mathrm{~mm} \times 115 \mathrm{~mm} \times 76 \mathrm{~mm}$, was adopted to simulate the size of Chamber Brick used in Chennai City (India).

The Compressed Stabilised Earth blocks were removed from the Moulds, and laid over a flat surface on the floor of the curing yard, under the shade of a sloped-roof shed. Mild water spray was used in the curing process.

Tests were conducted to determine the Compressive Strength and Moisture Absorption Ratio in the two categories of soil Specimens, namely, Laterite CSEBs and Clay CSEBs, on the $3^{\text {rd }}$ day, $7^{\text {th }}$ day $14^{\text {th }}$ day, $21^{\text {st }}$ day and $28^{\text {th }}$ day.

\section{RESULTS}

Results of Compressive strength for Laterite CSEBs are shown in Table-1 and Figure-1. On the $28^{\text {th }}$ day of Curing Age, the Laterite CSEBs attain a compressive Strength of 7.45 N/sq.mm, under a compaction of $28.0 \mathrm{MPa}$.

Referring to Table-2 and Figure-2, it can be seen that the Clay-CSEB attains a Compressive Strength of 5.05N/sq.mm, on the $28^{\text {th }}$ day.

Table 1 Compressive Strength in Laterite Soil Block

\begin{tabular}{|c|c|c|c|c|}
\hline S.No. & Curing Age(days) & $\mathbf{1 4 . 0 M P a}$ & $\mathbf{2 1 . 0 M P a}$ & 28.0MPa \\
\hline 1 & 3 & 6.3 & 6.6 & 7.05 \\
\hline 2 & 7 & 6.60 & 6.65 & 7.10 \\
\hline 3 & 14 & 6.65 & 6.75 & 7.20 \\
\hline 4 & 21 & 6.85 & 7.05 & 7.35 \\
\hline 5 & 28 & 7.00 & 7.20 & 7.45 \\
\hline
\end{tabular}


Priji E. Moses, Dr. M.P. Chockalingam, Dr. R. Venkatakrishnaiah, P. Dayakar

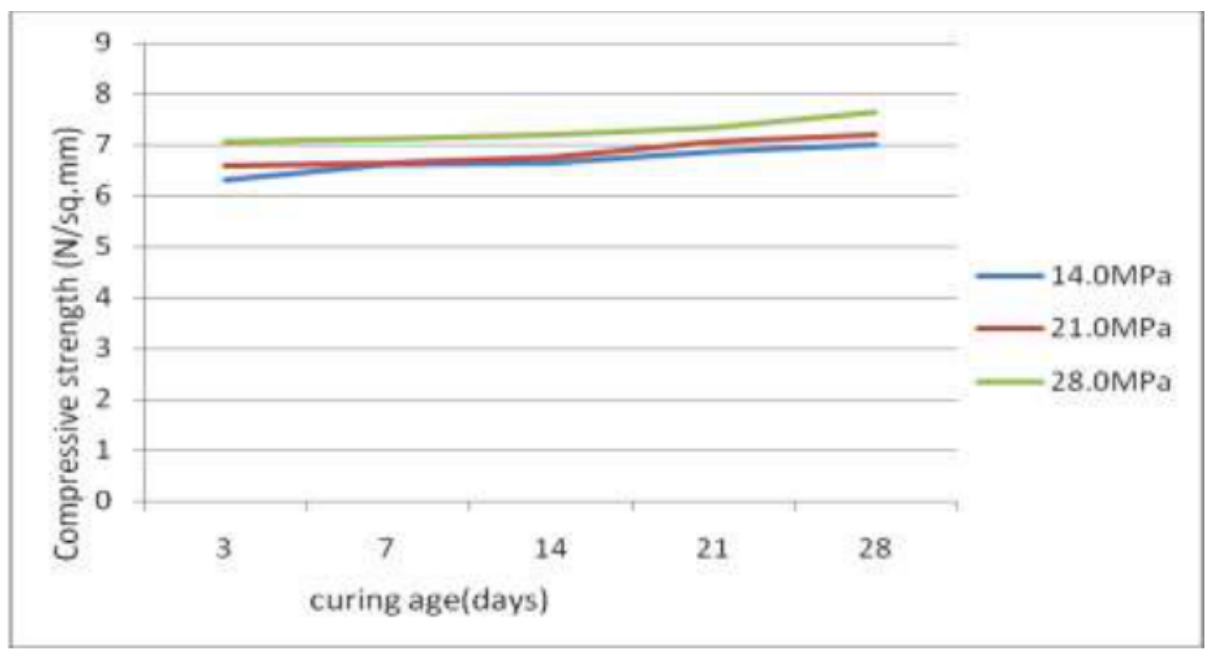

Figure 1 Variation of Compressive Strength of Laterite CSEB With Curing Age

Table-2 describes the variation of Compressive Strength with Curing Age, when compaction pressures are applied at $14 \mathrm{Mpa}, 21 \mathrm{MPa}$ and $21 \mathrm{MPa}$.

Table 2 Compressive Strength in Clay Soil Block

\begin{tabular}{|c|c|c|c|c|}
\hline S.No. & $\begin{array}{c}\text { Curing } \\
\text { Age(days) }\end{array}$ & $\mathbf{1 4 M P a}$ & 21MPa & 28MPa \\
\hline 1 & 3 & 4.00 & 5.50 & 5.60 \\
\hline 2 & 7 & 3.80 & 5.40 & 5.55 \\
\hline 3 & 14 & 3.45 & 5.10 & 5.35 \\
\hline 4 & 21 & 3.10 & 4.85 & 5.20 \\
\hline 5 & 28 & 2.75 & 4.55 & 5.05 \\
\hline
\end{tabular}

The Figure-2 describes the variation of compressive strength with Curing age when compaction pressures of $14 \mathrm{Mpa}, 21 \mathrm{MPa}$ and $28 \mathrm{MPa}$ are apllied to Clay-CSEBs.

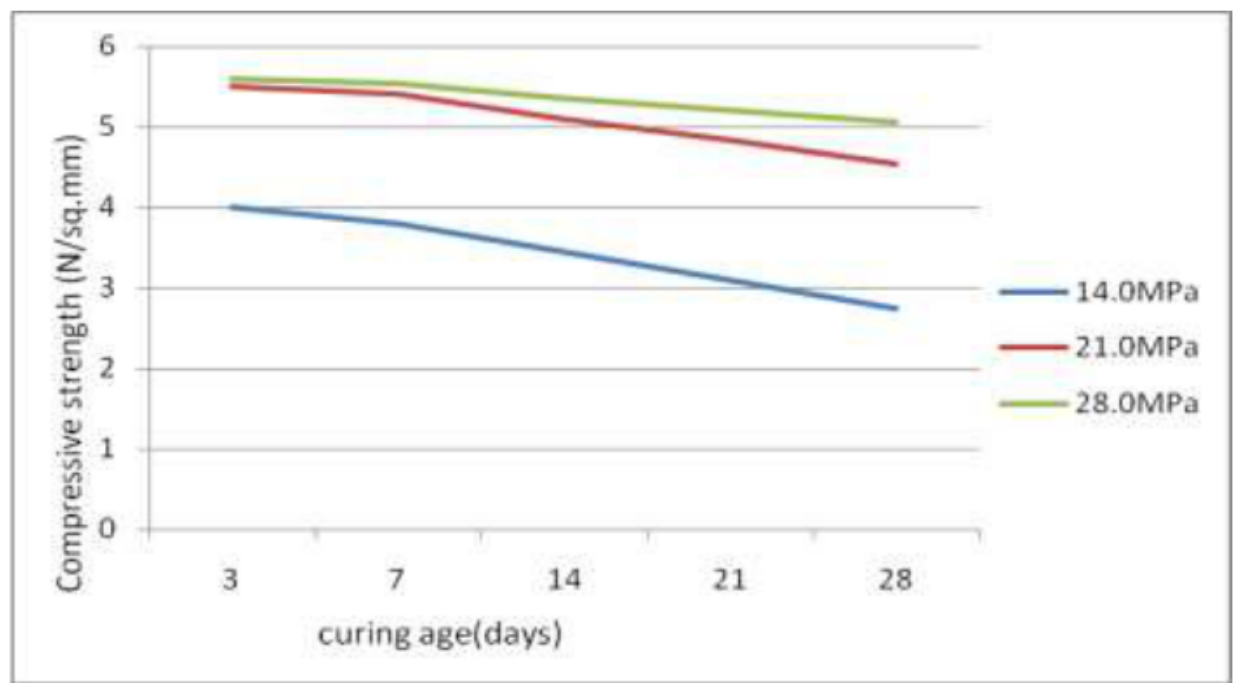

Figure 2 Variation of Compressive Strength during Curing Age, in the case of Clay-CSEBs.

Table-3 presents the variation of Moisture Absorption rate (\%) during the curing ages of 3-days, 7-days, 14-days, 21-days and 28-days, under the compression level of $14 \mathrm{MPa}, 21 \mathrm{MPa}$ and $28 \mathrm{MPa}$, for the Laterite Block. On the $28^{\text {th }}$ day, the Moisture Absorption rate was $14.95 \%$ under the compaction of $28 \mathrm{MPa}$. 
Advantage of Laterite over Clay in the Manufacture of Compressed Stabilized Earth Bricks

(CSEBs)

Table 3 Moisture Absorption Rate in Laterite Soil Block

\begin{tabular}{|c|c|c|c|c|}
\hline S.No. & $\begin{array}{c}\text { Curing } \\
\text { Age(days) }\end{array}$ & $\mathbf{1 4 . 0 M P a}$ & $\mathbf{2 1 . 0 M p a}$ & 28.0Mpa \\
\hline 1 & 3 & 15.60 & 15.75 & 16.05 \\
\hline 2 & 7 & 15.40 & 15.65 & 15.90 \\
\hline 3 & 14 & 15.10 & 15.35 & 15.65 \\
\hline 4 & 21 & 14.85 & 15.05 & 15.30 \\
\hline 5 & 28 & 14.50 & 14.75 & 14.95 \\
\hline
\end{tabular}

Figure-3 presents the variation of Moisture Absorption rate (\%) during the curing ages of 3 -days, 7-days, 14-days, 21-days and 28-days, under the compression level of $14 \mathrm{MPa}, 21 \mathrm{MPa}$ and $28 \mathrm{MPa}$, for the Laterite Block. On the $28^{\text {th }}$ day, the Moisture Absorption rate was $14.95 \%$ under the compaction of $28 \mathrm{MPa}$.

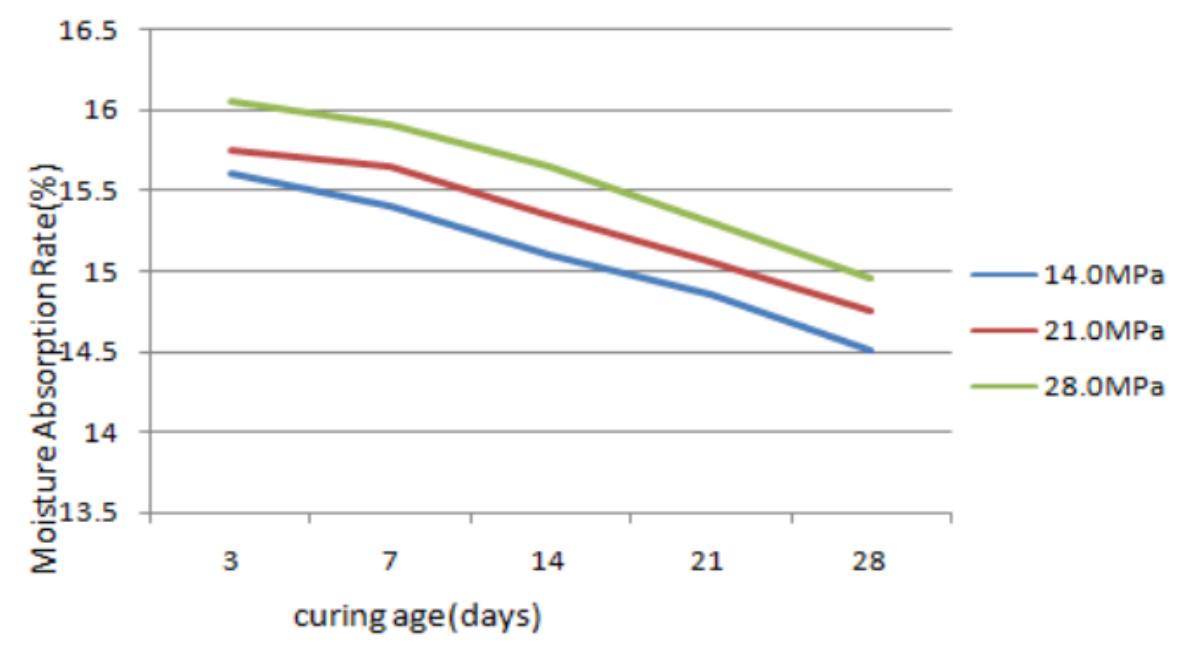

Figure 3 Variation of Moisture Content against Curing Age, In the case of Laterite-CSEBs.

From Table- 4 and Figure-4, it can be seen that the Moisture content on the $28^{\text {th }}$ day of Curing Age, was $21.05 \%$, in the case of Clay-CSEBs.

Table 4 Moisture Absorption in Clay Soil Block

\begin{tabular}{|c|c|c|c|c|}
\hline S.No. & $\begin{array}{c}\text { Curing } \\
\text { Age(days) }\end{array}$ & $\mathbf{1 4 . 0 M P a}$ & $\mathbf{2 1 . 0 M P a}$ & $\mathbf{2 8 . 0 M P a}$ \\
\hline 1 & 3 & 17.05 & 18.70 & 19.50 \\
\hline 2 & 7 & 17.25 & 19.00 & 19.75 \\
\hline 3 & 14 & 17.70 & 19.60 & 20.20 \\
\hline 4 & 21 & 18.10 & 20.15 & 20.70 \\
\hline 5 & 28 & 18.50 & 20.70 & 21.05 \\
\hline
\end{tabular}


Priji E. Moses, Dr. M.P. Chockalingam, Dr. R. Venkatakrishnaiah, P. Dayakar

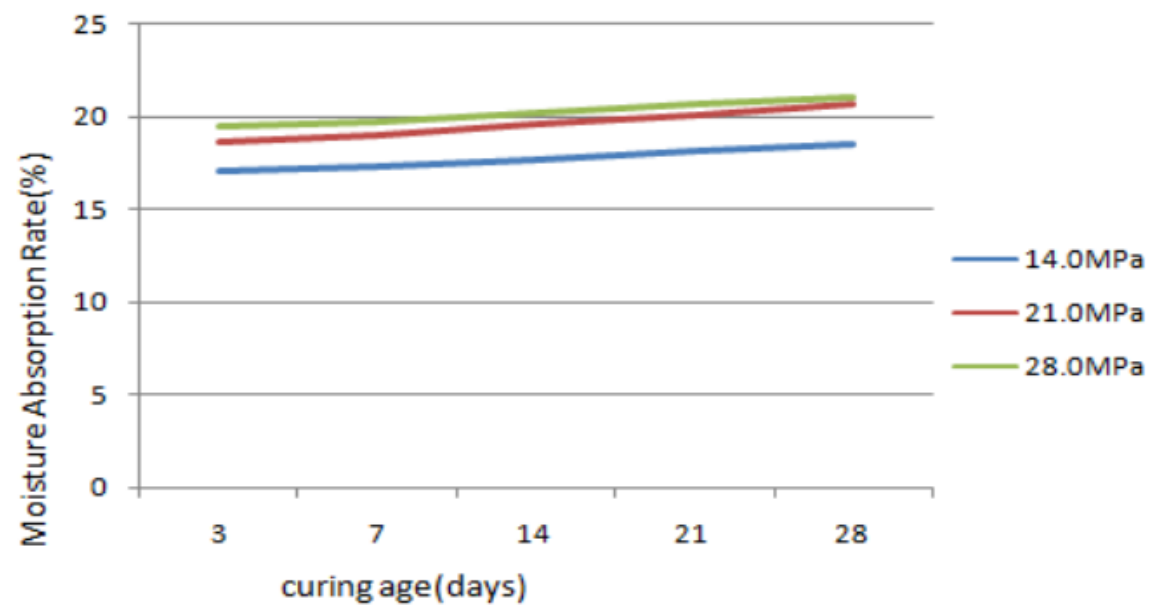

Figure 4 Variation of Moisture Content against Curing Age, In the case of Clay-CSEBs.

The Clay-CSEBs show an upward increasing trend of moisture absorbing rate, whereas in the case of Laterite-CSEBS, the Moicsture Absorbing rate showed a decreasing trend toward the Curing Age.

\section{CONCLUSIONS}

- Moisture Absorption rate varies from $15.90 \%$ on the $7^{\text {th }}$ day of curing, in the Laterite CSEBs to $14.95 \%$, at a steady state, under the Compaction of $28.0 \mathrm{MPa}$, showing a decreasing trend with time during the curing process. On the contrary, the Clay CSEBs indicate a Moisture Absorption rate variation of $19.75 \%$ on the $7^{\text {th }}$ day of curing to $21.05 \%$ on the $28^{\text {th }}$ day of curing under the compaction pressure of $28.0 \mathrm{MPa}$, registering an increasing trend during the curing period.

- Laterite CSEB gives a compressive strength of $7.45 \mathrm{~N} / \mathrm{sq} . \mathrm{mm}$, and Clay CSEB gives a compressive strength of $5.05 \mathrm{~N} / \mathrm{sq} . \mathrm{mm}$, when cement is added at $10 \%$ in both cases, and when a compaction of $28 \mathrm{MPa}$ is applied while manufacturing the CSEBs.

- The Laterite soil is found to be a better choice for making CSEBs wherever the Laterite soil is available as a natural resource.

\section{REFERENCES}

[1] M.R. Jones and A. McCarthy, Preliminary Views on the Potential of Foamed Concrete as a Structural Materials, Magazine of Concrete Research, 7(1), 21-31,(2005).

[2] C. Jayasinghe and N. Kamaladasa. Compressive strength characteristics of cement stabilized rammed earth walls, Univ. of Moratuwa, Sri Lanka, 1978-1976, (2006).

[3] A. H. Abdullah, S.K.A. Bakar and I.A. Rahman, Indoor Thermal Performance of an Office Building Using Conventional Brick Versus Interlocking Compressed Earth Brick (ICEB) wall, Int. J. of Construction Technology and Management, 1(1), 22-27, (2013)

[4] S.K. Abu Bakar and A.H. Abdullah, Simulation of Thermal Performance in an Office, Business Engineering and Industrial Applications Colloquium, IEEE, 318-323, (2012).

[5] N. Ali, N.A. Zainal, M.K. Burhanudin, A.A.A. Samad, N. Mohamad, S. Shahidan and S.R. Abdullah, Physical and Mechanical Properties of Compressed Earth Brick (CEB) containing sugarcane bagasse ash, MATEC Web Conf., 47, 1-7. (2016). 
Advantage of Laterite over Clay in the Manufacture of Compressed Stabilized Earth Bricks (CSEBs)

[6] S. Shahidan, H.B. Koh, A.S. Alansi and L.Y. Loon, Strength Development and Water Permeability of Engineered Biomass Aggregate Pervious Concrete, MATEC Web Conf., 47, 2-7, (2016).

[7] V. Rigassi and P. OdulCRATerre-EAG, Compressed Earth Blocks: Manual of Production, Vol. I: Manual of Production, A Publication of the Deutsches Zentrum Fur Entwicklungs Technologien-GATE, 6, (1985)

[8] UNESCO Chair Earthen Architecture, Compressed Stabilized Earth Block, Auroville Earth Institute, (2010).

[9] M.A. Yahaya, Mengkaji penggunaan tiang kapur terhadap enapan tanah bukan berstruktur kejuruteraan, Final Year Project Thesis, Universiti Teknologi Malaysia, (2008)

[10] Abdulaah Abd Halid, Nagapan S., Antonyova A., Rasiah K., Yunus R., and Sohu S., 2017, "Comparison of Strength between Laterite Soil and Clay Compressed Stabilised Earth Bricks (CSEBs)", MATEC Web of Conferences, 103, 01029(2017), ISCEE 2016. (DOI: $10.1051 /$ matecconf/201710301029).

[11] H. Guillaud, T. Joffroy OdulCRATerre-EAG, Compressed Earth Blocks: Manual of design and construction, Vol. II: Manual of design and construction, A publication of The Deutsches Zentrum fur Entwicklungs technologien-GATE, 8, (1985).

[12] M. Shariman, Pembaikan tanah liat marin dengan pendekatan saliran pugak, Final Year Project Thesis, UniversitiTeknologi Malaysia, (2008)

[13] R. Abdeldjebar, A. Hamouine, F. Fouchal, B. Labbaci and A. Zebair, Effects of Treated Date Palm Fiber on Durability of Stabilized Earth Blocks (SEB), International Journal of Civil Engineering and Technology, 9(5), 2018, pp. 293-305

[14] Mohamed TATANE, Hajar AKHZOUZ, Hassan ELMINOR and M'bark FEDDAOUI, Thermal, Mechanical and Physical Behavior of Compressed Earth Blocks Loads by Natural Wastes, International Journal of Civil Engineering and Technology, 9(6), 2018, pp. $1353-1368$

[15] M. Mukri, N. N. S.Aziz and N. Khalid, Geopolymer Effect in Modelling Hydraulic Conductivity for Designing Soil Liner of Laterite Soil. International Journal of Civil Engineering and Technology, 9(7), 2018, pp. 1962-1974

[16] Zubair Saing, Vertical Deformation of Lime Treated Base (LTB) Model of Laterite Soil using Numerical Analysis. International Journal of Civil Engineering and Technology, 8(5), 2017, pp. 758-764. 